\title{
PEMANFAATAN JAMUR MIKORIZA UNTUK MENINGKATKAN PERTUMBUHAN DAN PRODUKSI TANAMAN JAGUNG (Zea mays L.)
}

\section{THE UTILIZATION OF MYCORRHIZA MUSHROOMS TO INCREASE THE GROWTH AND PRODUCTION OF CORN (Zea mays L.)}

\author{
Wina Dewi Putri ${ }^{1)}$, Eddy Susiawan ${ }^{2}$ \\ 1)Mahasiswa Budidaya Tanaman Pangan, Politeknik Pertanian Negeri Payakumbuh, Kab. Limapuluh Kota, \\ Indonesia \\ 2)Dosen Prodi Budidaya Tanaman Pangan, Politeknik Pertanian Negeri Payakumbuh, Kab. Limapuluh Kota, \\ Indonesia \\ *penulis korespondensi \\ 1) putri.winna@gmail.com, ${ }^{2}$ eksaura@gmail.com
}

\begin{abstract}
Abstrak
Jagung (Zea mays L.) merupakan komoditas pangan sumber karbohidrat kedua setelah beras yang sangat penting untuk ketahanan pangan. Jagung juga berperan penting dalam industri pakan ternak dan industri pangan. Dalam kurun lima tahun terakhir, kebutuhan jagung nasional untuk bahan industri pakan, makanan dan minuman meningkat $10 \%-15 \%$ pertahun. Salah satu teknologi yang dapat meningkatkan produksi tanaman jagung adalah penggunaan jamur mikoriza. Tanaman yang bermikoriza tumbuh lebih baik dari tanaman tanpa mikoriza. Penyebab utama adalah mikoriza secara efektif dapat meningkatkan penyerapan unsur hara baik unsur hara makro maupun mikro. Selain daripada itu akar yang bermikoriza dapat menyerap unsur hara yang belum tersedia bagi tanaman. Pelaksanaan kegiatan budidaya ini dilakukan di lahan praktek Politeknik Pertanian Negeri Payakumbuh, Tanjung Pati, Kecamatan Harau, Kabupaten Limapuluh Kota, Sumatera Barat. Waktu pelaksanaan dimulai pada bulan September 2015 sampai bulan Januari 2016. Budidaya tanaman jagung dilakukan pada luas lahan $300 \mathrm{~m} 2$. Luas lahan yang digunakan untuk teknologi adalah $250 \mathrm{~m} 2$ dan tanpa teknologi seluas $50 \mathrm{~m} 2$. Berdasarkan hasil pengamatan dan uji statistik, penggunaan jamur mikoriza dapat meningkatkan pertumbuhan vegetatif yaitu tinggi tanaman dan generatif yaitu jumlah biji perbaris dan jumlah bobot 100 biji. Pada lahan teknologi diperoleh produksi sebanyak $132 \mathrm{~kg} / 300 \mathrm{~m} 2$ (4,4 ton/ha), meningkat 22,85\% dibandingkan produksi tanpa teknologi yaitu $108 \mathrm{~kg} / 300 \mathrm{~m} 2$ (3,6 ton/ha).
\end{abstract}

Kata kunci :, arbuscular, jagung pipil, mikoriza

\begin{abstract}
Corn (Zea mays L.) is a food commodity that is the second source of carbohydrates after rice which is very important for food security. Corn also plays an important role in the animal feed industry and the food industry. In the last five years, the national demand for corn for the feed, food and beverage industry has increased by $10 \%$ $-15 \%$ per year. One technology that can increase corn production is the use of mycorrhizal fungi. Mycorrhizal plants grow better than non-mycorrhizal plants. The main cause is that mycorrhizae can effectively increase the absorption of nutrients, both macro and micro nutrients. In addition, mycorrhizal roots can absorb nutrients that are not yet available to plants. The implementation of this cultivation activity is carried out on the land of the Payakumbuh State Agricultural Polytechnic practice, Tanjung Pati, Harau District, Limapuluh Kota Regency, West Sumatra. The implementation time starts from September 2015 to January 2016. Corn cultivation is carried out on an area of $300 \mathrm{~m}^{2}$. The land area used for the technology is $250 \mathrm{~m}^{2}$ and without technology $50 \mathrm{~m}^{2}$ Based on the results of observations and statistical tests, the use of mycorrhizal fungi can increase vegetative growth, namely plant height and generative, namely the number of seeds per row and total weight of 100 seeds. On technology land, the production is $132 \mathrm{~kg} / 300 \mathrm{~m} \mathrm{diperoleh}^{2}$ (4.4 tons/ha), an increase of $22.85 \%$ compared to production without technology which is $108 \mathrm{~kg} / 300 \mathrm{~m}^{2}$ (3.6 tons/ha).
\end{abstract}

Keywords: arbuscular, corn, mycorrhiza 


\section{Pendahuluan}

Jagung (Zea mays L.) merupakan komoditas pangan sumber karbohidrat kedua setelah beras yang sangat penting untuk ketahanan pangan. Jagung juga berperan penting dalam industri pakan ternak dan industri pangan. Menurut Budiman (2010), dalam kurun lima tahun terakhir, kebutuhan jagung nasional untuk bahan industri pakan, makanan dan minuman meningkat $10 \%-15 \%$ pertahun.

Pengembangan jagung diarahkan untuk mewujudkan Indonesia menjadi produsen jagung yang tangguh dan mandiri pada tahun 2025 dengan ciri-ciri produksi yang cukup dan efisien, kualitas dan nilai tambah yang berdaya saing, penguasaan pasar yang luas, meluasnya peran stakeholder, serta adanya dukungan pemerintah yang kondusif. Pada periode 2005-2025, produksi jagung nasional diproyeksikan rata-rata tumbuh sebesar 4,26\%. Dengan penduduk 216 juta jiwa, Indonesia saat ini membutuhkan bahan pangan pokok sekurang-kurangnya 53 juta ton beras, 12,5 juta ton jagung dan 3,0 juta ton kedelai. Jika tidak diimbangi dengan laju pertumbuhan produksi pangan dalam negeri secara signifikan, dapat menyebabkan ketahanan pangan nasional rendah (Hutapea dan Mashar, 2010).

Permintaan pasar yang terus meningkat menjadi tantangan dan peluang bagi petani jagung, dengan meningkatnya permintaan terhadap jagung maka petani mempunyai kesempatan untuk mengembangkan usaha dan meningkatkan produksi jagung per hektarnya. Peningkatan produksi pertanian, khususnya tanaman jagung sangat ditentukan oleh meningkatnya pengetahuan dan keterampilan petani dalam mengadopsi suatu teknologi sebagai upaya untuk memenuhi kebutuhan serta permintaan pasar (Perwarno dan Hartono, 2007).

Peningkatan produksi pangan nasional, dapat dilakukan dengan cara meningkatkan produktivitas yaitu menerapkan teknologi produksi antara lain melalui penggunaan pupuk organik/hayati. Pupuk tersebut dapat mengembalikan kesuburan lahan melalui jasa mikroba yang menguntungkan. Sejalan dengan itu, juga perlu dilakukan perluasan lahan pertanian antara lain melalui pengembangan kawasan transmigrasi.

Mikoriza merupakan suatu bentuk simbiosis mutualistik antara jamur dan akar tanaman. Penggunaan mikoriza ini dapat meningkatkan produksi jagung yang mengalami kekeringan sesaat pada fase vegetatif dan generatif. Mikoriza juga sangat berperan dalam meningkatkan toleransi tanaman terhadap kondisi lahan kritis, yang berupa kekeringan dan banyak terdapatnya logam-logam berat (Brianadi, 2007).

Tanaman yang bermikoriza tumbuh lebih baik dari tanaman tanpa bermikoriza. Penyebab utama adalah mikoriza secara efektif dapat meningkatkan penyerapan unsur hara baik unsur hara makro maupun mikro. Selain daripada itu akar yang bermikoriza dapat menyerap unsur hara dalam bentuk terikat dan yang tidak tersedia bagi tanaman (Mollah, Nasaruddin dan Zakaria, 2010). Inokulasi mikoriza mampu meningkatkan persentase infeksi mikoriza sehingga berpengaruh terhadap tinggi tanaman dan hasil produksi tanaman jagung. Adanya pengaruh nyata dan tinggi tanaman dan hasil jagung akibat inokulasi mikoriza disebabkan lebih tingginya serapan P pada tanaman yang diinokulasi mikoriza. Fungsi $\mathrm{P}$ bagi tanaman antara lain adalah untuk pembelahan sel, pembentukan bunga, buah, biji serta mempercepat kematangan, dan meningkatkan produksi sekitar 55\% (Brianadi, 2007). 


\section{Metode Penelitian}

Kegiatan budidaya jagung dengan pemberian teknologi jamur mikoriza merupakan tugas akhir dilaksanakan selama 4 bulan, mulai dari bulan September 2015 dan berakhir pada bulan Januari 2016. Jadwal. Pelaksanaan kegiatan ini dilakukan pada lahan praktek Politeknik Pertanian Negeri Payakumbuh, Tanjung Pati, Kecamatan Harau, Kabupaten Limpuluh Kota, Sumatera Barat.

Alat-alat yang digunakan selama pelaksaan kegiatan ini antara lain cangkul, tugal, garu, gembor, koret, ember, tali rafia, meteran dan pisau. Bahan yang dibutuhkan diantaranya karung, benih jagung hibrida Pioner 21, jamur mikoriza, pupuk Urea, pupuk SP36, dan pupuk KCl.

\section{Hasil dan Pembahasan}

Hasil analisis data pengamatan dengan menggunakan uji t 5\% dapat dilihat pada tabel di bawah ini:

Tabel 1. Hasil analisis data uji t terhadap pengamatan vegetatif antara perlakuan teknologi dan tanpa teknologi

\begin{tabular}{lllll}
\hline Parameter & Teknologi & $\begin{array}{l}\text { Tanpa } \\
\text { teknologi }\end{array}$ & $\begin{array}{c}\mathrm{t} \\
\text { hitung }\end{array}$ & $\begin{array}{l}\text { Hasil } \\
\text { Uji t }\end{array}$ \\
\hline $\begin{array}{l}\text { Tinggi } \\
\text { tanaman (cm) }\end{array}$ & 218,2 & 186,7 & 24,55 & HS \\
$\begin{array}{l}\text { Jumbh daun } \\
\text { (helai) }\end{array}$ & 13,2 & 12,7 & 1,30 & NS \\
$\begin{array}{l}\text { Lebar daun } \\
\text { (cm) }\end{array}$ & 11,0 & 10,9 & 0,44 & NS \\
$\begin{array}{l}\text { Panjang daun } \\
\text { (cm) }\end{array}$ & 99,0 & 99,5 & $-0,66$ & NS \\
\hline
\end{tabular}

Ket: $\mathrm{t}$ tabel $5 \%$ 2,02, $\mathrm{t}$ tabel $1 \% 2,71$

NS*berbeda tidak nyata,

HS*berbeda sangat nyata

Dari tabel di atas dapat dilihat bahwa pertumbuhan vegetatif tanaman jagung dengan pemberian teknologi jamur Mikoriza maupun tanpa diperoleh hasil yang berbeda sangat nyata pada pengamatan tinggi tanaman jagung, tetapi memperoleh hasil yang berbeda sangat nyata pada pengamatan jumlah daun, lebar daun dan panjang daun.Untuk melihat perbedaan yang lebih jelas pada perbedaan tinggi tanaman, jumlah daun, lebar daun dan panjang daun antara teknologi maupun teknologi dapat dilihat pada tabel dan grafik berikut ini: 
a. Tinggi tanaman

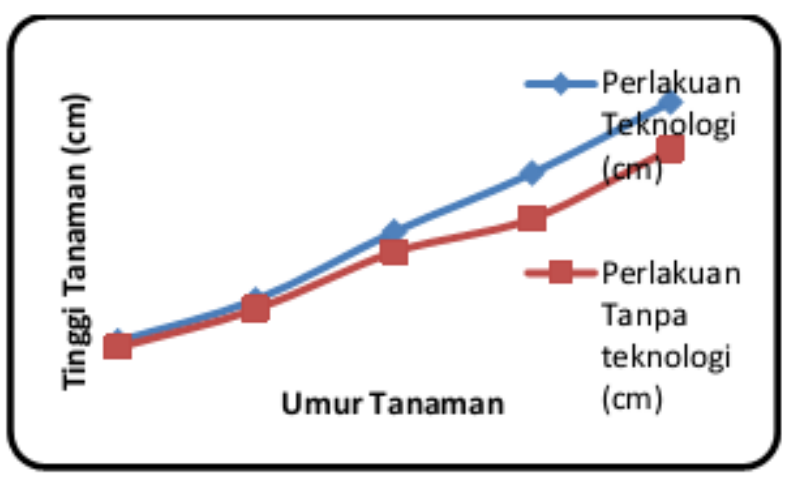

Gambar.1. Grafik tinggi tanaman dengan teknologi dan tanpa teknologi Sumber: Hasil olah data pribadi

b. Jumlah daun

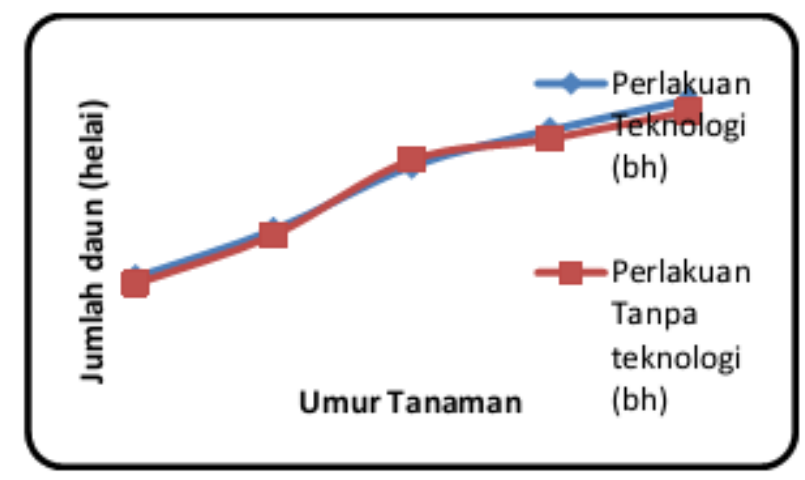

Gambar.2. Grafik pertambahan jumlah daun tanaman jagung teknologi dan tanpa teknologi Sumber: Hasil olah data pribadi

c. Lebar daun

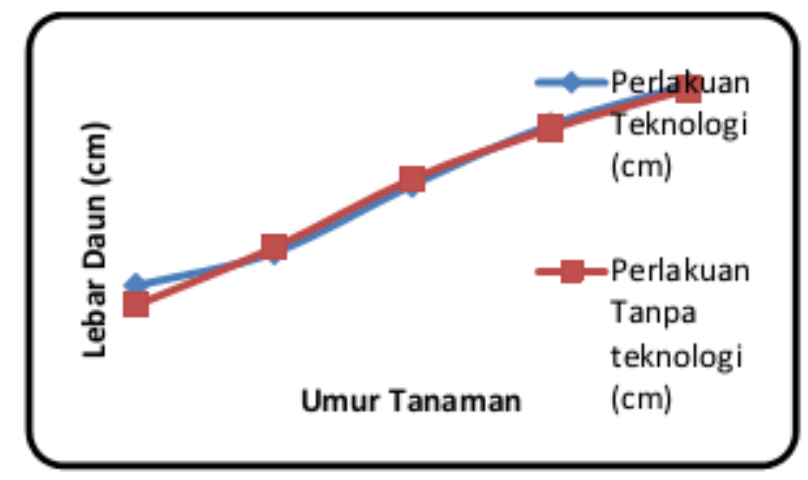

Gambar.3. Grafik pertambahan lebar daun dengan teknologi dan tanpa teknologi Sumber: Hasil olah data pribadi 
d. Panjang daun

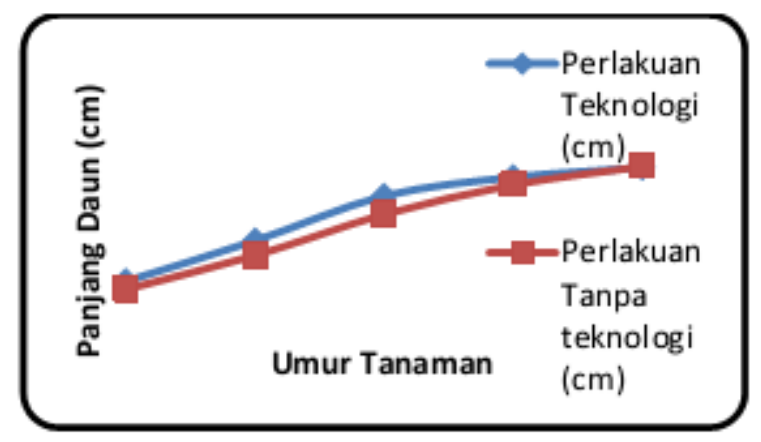

Gambar.4. Grafik panjang daun dengan teknologi dan tanpa teknologi Sumber: Hasil olah data pribadi

Berdasarkan grafik di atas, dapat dilihat bahwa laju pertumbuhan vegetatif tanaman jagung pada pengamatan tinggi tanaman dengan teknologi meningkat, sedangkan pada pengamatan jumlah daun, lebar dan panjang daun tidak terlalu tinggi jika dibandingkan dengan tanaman tanpa teknologi. Untuk jumlah daun pertumbuhan tanaman yang menggunakan teknologi meningkat dibanding dengan tanpa teknologi. Pada pengamatan lebar daun laju pertumbuhan tanaman dengan teknologi meningkat dibandingkan dengan tanaman tanpa teknologi, dan pada lebar daun laju pertumbuhan tanaman dengan teknologi lebih meningkat dibanding tanpa teknologi.

\section{Pertumbuhan generatif (komponen hasil)}

Tabel.2. Hasil analisis data uji t terhadap pengamatan generatif (komponen hasil) antara teknologi dan tanpa teknologi)

\begin{tabular}{|c|c|c|c|c|c|c|}
\hline \multirow{2}{*}{ Parameter } & \multirow{2}{*}{ Teknologi } & \multirow{2}{*}{$\begin{array}{c}\text { Tanpa } \\
\text { teknologi }\end{array}$} & \multirow{2}{*}{$\begin{array}{c}\mathrm{t} \\
\text { hitung }\end{array}$} & \multicolumn{2}{|c|}{$\mathrm{t}$ tabel } & \multirow{2}{*}{$\begin{array}{c}\text { Hasil } \\
\text { uji t }\end{array}$} \\
\hline & & & & $5 \%$ & $1 \%$ & \\
\hline $\begin{array}{l}\Sigma \text { Baris per } \\
\text { tongkol }\end{array}$ & 15,6 & 14,7 & 2,48 & 2,024 & 2,71 & $\mathrm{~S}$ \\
\hline$\Sigma$ Biji per baris & 38,4 & 36,3 & 3,92 & 2,48 & 2,71 & HS \\
\hline Bobot 100 biji & 49,7 & 45,8 & 5,87 & 2,48 & 2,71 & HS \\
\hline $\begin{array}{l}\Sigma \\
\text { tongkol/tanaman }\end{array}$ & 1 & 1 & - & - & - & - \\
\hline
\end{tabular}

Ket: $\mathrm{t}$ tabel 5\% 2,02, $\mathrm{t}$ tabel $1 \% 2,71$

$\mathrm{S} *$ berbeda nyata,

HS*berbeda sangat nyata

Berdasarkan Tabel 2, data pengamatan jumlah baris pertongkol antara sampel tanaman teknologi dan tanpa teknologi adalah signifikan atau berbeda nyata. Sementara itu, data pengamatan jumlah biji per baris dan bobot 100 biji menunjukkan hasil yang berbeda sangat nyata. Perbedaan tersebut akan terlihat jelas apabila dilihat dari diagram di bawah ini: 
a. Jumlah baris/tongkol

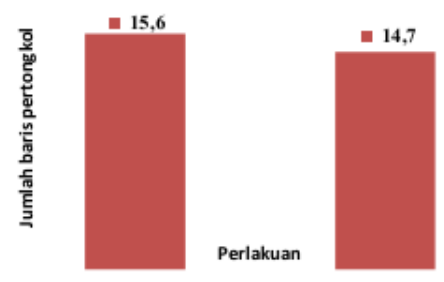

Gambar 5. Diagram perbandingan jumlah baris per tongkol tanaman jagung dengan pemberian kompos limbah pasar dan tanpa pemberian kompos limbah pasar Sumber: Hasil olah data pribadi

b. Jumlah biji/baris

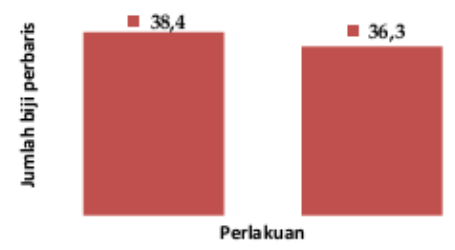

Gambar 6. Diagram perbandingan jumlah biji per baris dengan pemberian kompos limbah pasar dan tanpa pemberian kompos limbah pasar Sumber: Hasil olah data pribadi

c. Bobot 100 biji

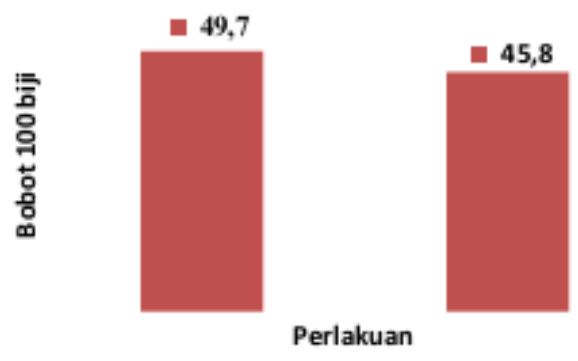

Gambar 7. Diagram perbandingan bobot 100 biji tanaman jagung dengan pemberian kompos limbah pasar dan tanpa pemberian kompos limbah pasar

Sumber: Hasil olah data pribadi

Berdasarkan diagram pengamatan generatif di atas terlihat bahwa tanaman jagung yang diberi teknologi lebih tinggi dibandingkan tanaman tanpa teknologi. Hal ini berarti pemanfaatan jamur mikoriza untuk tanaman jagung dapat memberi peluang untuk meningkatkan produksi tanaman jagung. 
Tabel.3 Produksi tanaman jagung dengan luas lahan $300 \mathrm{~m} 2$ dan 1 ha

\begin{tabular}{lcccc}
\hline & Produk & & $\begin{array}{c}\text { Jumlah } \\
(\mathrm{Kg})\end{array}$ & Produksi/ha \\
\hline $\begin{array}{l}\text { Jagung } \\
\text { teknologi }\end{array}$ & pipil & dengan & 132 & 4,4 ton \\
$\begin{array}{l}\text { Jagung } \\
\text { teknologi }\end{array}$ & pipil & tanpa & 108 & 3,6 ton \\
\hline
\end{tabular}

\section{Pembahasan}

Berdasarkan Tabel 1 di atas dapat dilihat bahwa pada fase pertumbuhan vegetatif tanaman jagung yaitu pada pengamantan tinggi tanaman jagung dengan menggunakan teknologi jamur mikoriza dan tanpa pemberian jamur mikoriza menunjukkan hasil yang berbeda sangat nyata. Sedangkan pada hasil pengamatan jumlah daun, lebar daun dan panjang daun terpanjang menunjukkan hasil yang berbeda tidak nyata. Sementara itu, pada fase generatif jumlah biji per baris dan bobot 100 biji tanaman jagung menunjukkan hasil yang berbeda sangat nyata. Hal ini berarti pemanfaatan jamur mikoriza dapat berpengaruh terhadap produksi tanaman jagung. Jamur mikoriza merupakan bahan organik yang salah satu perannya terhadap sifat fisik tanah adalah meningkatkan kemampuan menahan air.

Cendawan Mikoriza adalah salah satu jenis mikroba tanah yang mempunyai kontribusi penting dalam kesuburan tanah dengan jalan meningkatkan kemampuan tanaman dalam penyerapan unsur hara seperti fosfat, air, dan nutrisi lainnya. Menurut Aldeman dan Morton, (1986) bahwa infeksi MVA dapat meningkatkan pertumbuhan tanaman dan kemampuannya memanfaatkan nutrisi terutama unsur $\mathrm{P}, \mathrm{Ca}, \mathrm{N}, \mathrm{Cu}, \mathrm{Mn}, \mathrm{K}, \mathrm{dan} \mathrm{Mg}$. Hal ini disebabkan karena kolonisasi Mikoriza pada akar tanaman dapat memperluas bidang serapan akar dengan adanya hifa eksternal yang tumbuh dan berkembang melalui bulu akar. Selanjutnya miselia cendawan Mikoriza dapat tumbuh dan menyebar keluar akar sekitar lebih $9 \mathrm{~cm}$, dengan total panjang hifanya dapat mencapai 26-54 m. akar yang bermikoriza dapat menyerap P dari larutan tanah pada konsentrasi dimana akar tanaman tidak bermikoriza, tidak dapat menjangkaunya. Hal ini disebabkan karena akar yang terinfeksi mikoriza mempunyai metabolisme energi lebih besar, sehingga aktif dalam pengambilan P.

Produksi yang diperoleh pada lahan teknologi adalah sebesar $132 \mathrm{~kg} / 300 \mathrm{~m} 2 \mathrm{atau} 4,4 \mathrm{ton} / \mathrm{ha}$ dan untuk lahan tanpa teknologi sebanyak 108 kg/300 m2atau 3,6 ton/ha. Produksi jagung dari lahan yang menggunakan jamur mikoriza lebih tinggi dibandingkan dengan lahan tanpa peberian jamur mikoriza, karena adanya pengaruh baik dari pemberian jamur mikoriza.

Produksi jagung pada lahan teknologi yang lebih tinggi dibandingkan dengan produksi pada lahan tanpa teknologi. Hal ini disebabkan karena tanaman yang bermikoriza tumbuh lebih baik dibandingkan dengan tanaman tanpa mikoriza. Hifa dari mikoriza beraktifitas dengan menyebar kedalam sistem akar tanaman. Hal ini sesuai dengan pendapat Tisdale, et al (1993) yang menytakan bahwa kemampuan intersepsi akar dalam pengambilan nutrisi dapat dipertinggi oleh mikoriza yang merupakan simbiosi antara jamur dan akar tanaman. Simbiosis jamur mikoriza dapat meningkatkan serapan unsur hara P. 
Produksi yang diperoleh belum mencapai target disebabkan oleh beberapa faktor, terutama pada saat fase vegetatif, kondisi cuaca tidak mendukung untuk pertumbuhan tanaman jagung. Keadaan cuaca pada awal penanaman sangat buruk untuk pertumbuhan karena kurangnya curah hujan akibat bencana kabut asap yang cukup lama sehingga kondisi tanah sangat kering. Akibatnya tanaman tidak dapat tumbuh optimal karena kurangnya ketersediaan air dan kurangnya intensitas cahaya matahari karena terhalang kabut asap. Tanaman jagung sangat membutuhkan cahaya matahari untuk pertumbuhannya yaitu mencapai $100 \%$. Jika tanaman jagung kekurangan cahaya maka akan berpengaruh terhadap proses metabolisme tanaman seperti fototosintesis. Pada saat benih selesai ditanam tidak adanya curah hujan sehingga terjadi kekeringan. Pada saat tanaman berumur 7-35 hari setelah berkecambah titik tumbuh telah berada di atas permukaan tanah, sehingga kekeringan pada fase ini dapat menyebabkan perkembangan akar dan pemanjangan batang menjadi lambat (Anonim, 2014). Cahaya yang cukup merupakan salah satu syarat bagi tanaman untuk bisa melakukan proses fotosintesis, tidak maksimalnya sinar matahari yang diperoleh tanaman maka akan dapat menurunkan produksi (Hermanto, 2015).

Pada saat mendekati panen kondisi cuaca berada pada curah hujan yang tinggi, sehingga terdapat tongkol tanaman jagung yang terserang penyakit busuk tongkol. Penyakit ini disebabkan oleh infeksi cendawan Fusarium moniliforme. Penyakit ini dikendalikan secara mekanis karena hanya beberapa tongkol yang terserang yaitu dengan cara membuang tongkol yang terserang cendawan agar tongkol yang lainnya tidak ikut terinfeksi oleh cendawan tersebut. Selain penyakit ini, di temui juga tongkol yang bijinya telah tumbuh dan adanya tongkol yang diserang hama semut rang-rang. Semut ini memakan biji memakan biji dan juga tongkol sehingga tongkol yang diserang menjadi hancur dan rapuh. Namun tingkat serangannya sangat kecil.

\section{Kesimpulan dan Saran}

Pemanfaatan jamur mikoriza berpengaruh sangat nyata terhadap tinggi tanaman jagung dan berpengaruh tidak nyata terhadap jumlah daun, lebar daun dan panjang daun. Persentase peningkatan produksi jagung dengan teknologi mikoriza yaitu $22,2 \%$. Produksi yang diperoleh pada tanaman yang diberi teknologi adalah 4,4 ton/ha dan tanpa teknologi adalah 3,6 ton/ha. Berdasarkan hasil Laporan Tugas Akhir ini, penulis menyarankan untuk lebih mengoptimalkan dosis mikoriza yang digunakan untuk meningkatkan produksi tanaman jagung serta harus memperhatikan waktu tanam dan keadaan musim yang sesuai dengan kebutuhan tanaman jagung.

\section{Ucapan Terimakasih}

Puji syukur penulis panjatkan kehadirat Allah SWT yang telah memberikan rahmat dan hidayah-Nya khususnya bagi penulis yang telah menyelesaikan Laporan Tugas Akhir dengan judul "Pemanfaatan Jamur Mikoriza Untuk Meningkatkan Pertumbuhan Dan Produksi Jagung (Zea mays L.)”

Penyusunan Laporan ini sebagai salah satu syarat untuk meraih gelar Ahli Madya (A.md) Program Studi Budidaya Tanaman Pangan, Jurusan Budidaya Tanaman Pangan, Politeknik Pertanian Negeri Payakumbuh. 


\section{Daftar Pustaka}

Aldeman, J.M., and J.B. Morton. 1986. Invek-tivity of vesicular-arbuscular my-corrhizal fungi influence host soil dilu-ents combination on MPN estimates and percentage colonization. Soil Biol-chen. 8(1):77-83

Anonim. 2014. Fase pertumbuhan tanaman jagung. http://repository.unhas.ac.id/bitstream/hand le/123456789/3048/BAB\%20II\%20Tinjaua n\%20Pustaka-1.docx?sequence=3

Brianadi. 2007. Mikoriza peran prospek dan kendalanya. http://mti.ugm.ac.id/ bri anadi /2007/04/23/mikorizaperan-prospek-dan-kendalanya/.

Hermanto, C. 2015. Kabut asap berpotensi turunkan produktivitas tanaman. http://www.medanbisnisdaily.com/m/news/ read/2015/10/08/191170/kabut-asap-berpotensi-turunkanproduktivitas-tanaman/. Diunduh Tanggal 03 Januari 2016

Hutapea, J,. A,Z, Mashar. 2010. Ketahanan pangan dan teknologi produktivitas menuju kemandirian pertanian Indonesia. http://zaifbio.com/2010/05/31/ ketahanan-pangan-dan-teknologi-produktivitas-menujukemandirian-pertanian-indonesia/

Mollah, A., Nasaruddin dan B. Zakaria. 2010.Aplikasi pupuk mikorizasebagai pupuk hayati. http://repository.unhas.ac.idhandle1234567893849.html

Perwarno dan R. Hartono. 2007. Bertanam Jagung Unggul. Penebar Swadaya. Jakarta. Rukmana, R. 1997. Usaha Tani Jagung. Kanisius. Yogyakarta.

Simanungkalit. 2008. Cendawan Mikoriza arbuskuler 